\title{
THE INFLUENCE OF GLOBAL MUSLIM FEMINISM ON INDONESIAN MUSLIM FEMINIST DISCOURSE
}

\section{Nina Nurmila}

The Postgraduate Program of the State Islamic University (UIN) Bandung, Indonesia

\section{Abstract}

Since the early 1990s, many Muslim feminist works have been translated into Indonesian. These are, for example, the works of Fatima Mernissi, Riffat Hassan, Amina Wadud, Asghar Ali Engineer, Nawal Saadawi, Asma Barlas and Ziba Mir-Hossaini. These works have been influential in raising the awareness of Indonesian Muslims concerning Islam as a religion which supports equality and justice, but whose message has been blurred by patriarchal interpretations of the Qur'an which mostly put men in the superior position over women. Influenced by Muslim feminists from other countries, there has been an increasing number of Indonesian Muslim scholars, both male and female, who have challenged the existing male biased Qur'anic interpretations on gender relations. These scholars, for instance, are Lily Zakiyah Munir, Nasaruddin Umar, Zaitunah Subhan, Musdab Mulia and Nurjannah Ismail. This paper aims to shed some light on the influence of non-Indonesian Muslim feminist works on Indonesian Muslim feminist discourse. It will also discuss some of the reactions of Indonesian Muslims to the works of Muslim feminists. While some argue for the reinterpretation of the Qur'anic verses from the perspective of gender equality, others feel irritation and anger with the contemporary Muslim feminist critique of the classical Muslim interpretations of the Qur'an, mistakenly assuming that Muslim feminists have criticized or changed the Qur'an. This feeling of anger, according to Asma Barlas, may be caused by the unconscious elevation in the minds of many Muslims 
of the classical figh and tafsir into the position of replacing the Qur'an or even putting these human works above the Qur'an. This, according to her, has unconsciously left the Qur'an "untouchable" (too sacred to be reinterpreted) for most contemporary Muslims.

Keywords: Muslim feminism, Islamism, Women, Education

\section{A. Introduction}

Feminism is an English term with many definitions. For example, Oxford Advanced Learners Dictionary of Current English defines feminism as a "movement for recognition of the claims of women for rights (legal, political etc) equal to those possessed by men". ${ }^{1}$ Karam defines feminism as: "An individual or collective awareness that women have been and continue to be oppressed in diverse ways and for diverse reasons, and attempts towards liberation from this oppression involving a more equitable society with improved relations between women and men". ${ }^{2} \mathrm{I}$ myself define feminism as "an awareness of the existing oppression or subordination of women because of their sex and as working to eliminate such oppression or subordination and to achieve equal gender relations between men and women". ${ }^{3}$

Feminism is a world-wide movement but it can be manifested in different ways in different countries. Even though women's subordination is a world-wide phenomenon, its forms may vary even though there may be many similarities among the countries. For example, women's subordination can be similarly manifested in domestic violence against women and discrimination in the workplace. But there are many other problems faced by Indonesian women which are not necessarily being faced by American women. For example, Indonesian women still have to struggle against arbitrary polygamy, under-aged and unregistered marriage, while American women may avoid marriage completely.

As part of the global society, Indonesia has affected and been

${ }^{1}$ Hornby, AS, Oxford Advanced Learners Dictionary of Current English (Oxford: Oxford University Press, 1987), p. 315.

${ }^{2}$ Azza Karam, Women, Islamism and the State: Contemporary Feminisms in Egypt (New York: St Martin's Press, 1998), p. 5.

3 Nina Nurmila, Women, Islam and Everyday Life: Renegotiating Polygamy in Indonesia (London: Routledge, 2009), p. 4. 
affected by what happens in other parts of that global society. For instance, feminism has been embraced by some Indonesians, especially those who have studied in Western countries. ${ }^{4}$ Upon returning to Indonesia, these women have used their knowledge to change the position of women. Some of these early feminists in the second half of the $20^{\text {th }}$ century, post-independent period, such as Debra Yatim, Myra Diarsi, Ratna Saptari, Sita Aripurnami and Syarifah Sabarouddin, have set up Non-Governmental Organisations (NGOs) like Kalyanamitra in 1985, aiming to raise awareness of women's rights. ${ }^{5}$ There are many other early Indonesian feminists in the post-independence period such as Julia Suryakusuma, Saparinah Sadeli, Kamala Chandrakirana and Tati Krisnawaty. Using Azza Karam's categorization of feminism in Egypt, ${ }^{6}$ these feminists can be categorized as secular feminists because

${ }^{4}$ One of the examples that Indonesia has affected international feminist discourse can be seen from Zainah Anwar's appreciation to the works written by many contemporary Indonesian Muslim feminists. Zainah Anwar is the founder and the director of Musawah, a global movement for equality and justice in the family. During Musawah Out Reach Strategy Meeting and Musawah Asia Strategy Meeting, attended by global Muslim feminists involved in the Musawah networks, such as from Asia, Africa, Australia, UK and USA, 3-10 August 2010 in Yogyakarta, in which I was involved in as a rapporteur of the event, Zainah pointed out the rich works that have been written by Indonesian feminists. By the end of the session, many Indonesian feminist books were sold out, especially by Malaysian and Thai feminists. Unfortunately, not all global feminists can read Indonesian Muslim feminist works due to the language barriers. This encourages Indonesian Muslim feminists to translate their works into English.

5 The influence of Western feminism had come to Indonesia prior to independence. This can be seen, for example, from Kartini's book which argues for women's rights for education and the Indonesian women's struggles, for example, to have codified marriage law to protect women from arbitrary polygamy, unilateral divorce and under-age and forced marriage, which began in the early 1900s. See Nurmila, Women, Islam and Everyday Life, p. 47.

${ }^{6}$ Azza Karam categorizes feminisms in Egypt into three: secular, Muslim and Islamist feminism. Secular feminists are those who use secular law or conventions such as the Convention for the Elimination of Discrimination against Women (CEDAW) as their basis for gender equality; Muslim feminists use Islam, mainly the Qur'an to liberate women. They argue that Qur'an has been interpreted to justify women's subordination, therefore to liberate women is to reinterpret the Qur'an from equal gender perspectives; Islamist feminists mostly do not like to be called feminists because they regard feminism as Western product. Unlike Muslim feminists, Islamist feminists believe that men and women are equal but complementary: men are leaders of the family while women are wives and mothers. Unlike Muslim feminists who tend to read the Qur'an 
even though they are mostly Muslims, they do not necessarily know much about Islamic teaching and therefore they use secular laws and conventions, both national and international, such as CEDAW, instead of Islam, in their struggle for gender equality. They are mostly educated in urban secular institutions such as the University of Indonesia or in Western education institutions abroad, and economically belong to the middle-upper class but with no experience of being educated in Islamic education institutions such as Islamic boarding school (pesantren) or the Institute for Islamic Studies.

In contrast to secular feminists, Muslim feminists use Islamic sources such as Qur'an and ḩadith in their struggle for gender equality. They are mostly graduates from Islamic institutions such as the State Islamic Institute for Islamic Studies (IAIN) or the State Islamic University (UIN) with pesantren background. Most of them originally come from rural areas with a low to middle class economic background. These Muslim feminists, for example, include Siti Musdah Mulia, Nasaruddin Umar, Zaitunah Subhan, Nurjannah Ismail, Kiayi Husein Muhammad, Faqihuddin Abdul Kodir, Siti Syamsiyatun, Siti Ruhaini Dzuhayatin and many more. I consider myself to be a Muslim feminist too. Like Azza Karam's categorization, Muslim feminists believe that the Qur'an liberates women. However, the Qur'an has been mostly interpreted to justify women's subordination and therefore to liberate women is to reinterpret the Qur'an from gender equality perspectives. Unlike the influence of secular feminism, which began in Indonesia earlier in the 1980s, the influence of Muslim feminism began later in Indonesia in the 1990s, when many Indonesian Muslim feminist "candidates" had, at least, their first degree of education.

This paper will shed some light on the influence of non-Indonesian Muslim feminist works on Indonesian Muslim feminist discourse. I will argue that global Muslim feminism has been embraced by Indonesian Muslims because it came at the right time, in the 1990s, when many Indonesian Muslim women were better educated. This paper will begin with the Indonesian context of women's education and its relationship to attitudes toward marriage, then consider the influence of global Muslim

contextually, Islamist feminists tend to read the Qur'an literally. See Azza Karam, Women, Islamism and the State, pp. 9-14. 
feminism on Indonesian Muslim feminist discourse, and conclude with how Indonesian Muslims reacted to this discourse. In general, Indonesian Muslims can be divided into two categories in their responses to Muslim feminism: (1) those who accept and adopt Muslim feminism for their academic and feminist activism, and who I categorize as Muslim feminists; and (2) those who reject and counter Muslim feminist publications with Islamist publications, and who I categorize as Islamist feminists. As with Karam's categorization, Islamist feminists do not like to be labeled as feminist due to the Western origins of the term. They support the complementary roles of men and women, in which women are housewives and mothers, whose main duties are to serve their husband and take care of their children, while men are the breadwinner of the family. For them, women can participate in the public sphere as long as they do not forget their duties to the family, which they consider to be naturally pre-determined [kodrat]. In Indonesia, these Islamist feminists among others are women activists of Muslimah Hizbut Tahrir Indonesia (Muslimah HTI) or members of Partai Keadilan Sejahtera/PKS (the Welfare Justice Party) who argue against gender equality.

\section{B. Indonesian Women's Education and the Changing Attitudes toward Marriage in the 1970s}

Women's education in Indonesia is related to attitudes toward marriage. To make this clear, I will divide Indonesian history into two periods: (1) from the 1950s to the 1970s; and (2) from the 1970s up to the present day. During the first period, women in Indonesia, especially in Java, were married off by the age of $17 .{ }^{7}$ This was partly due to poverty and the lack of education facilities, resulting in many girls not continuing their education beyond primary school level. During this period, if there was a girl who was not married by the age of 17 , she would be labeled as a spinster [perawan tua] and would be an embarrassment for her parents. To avoid embarrassment, some parents arranged for their daughter's marriage by that age or looked for a man who would temporarily marry their daughter for a week or so and then divorced her. If the couple were unhappy with their arranged marriage, the daughter could return to her

${ }^{7}$ Hildred Geertz, The Javanese Family: A Study of Kinship and Socialization (USA: The Free Press of Glencoe, 1961), p. 56. 
parents after the divorce. After the divorce, it would be easier for the daughter to find a husband who might be embarrassed to be involved in an elaborate wedding celebration. ${ }^{8}$

At that time, marriage was the business of parents, not a personal choice. Parents had several interests in their children's marriage. For instance, many parents were afraid their daughter might not choose the right spouse and would fall into the hands of a womanizer. ${ }^{9}$ Moreover, they tended to protect family honor by marrying off their daughter at an early age or as soon as they reached puberty to avoid sexual misconduct and pregnancy outside marriage. ${ }^{10}$ In addition, some parents were motivated by the economic interests of receiving gifts during the elaborate wedding feast from their guests in return for the donations they had made in the past. ${ }^{11}$ Wedding feasts celebrating their daughter's first marriage also served to show the social status of parents within their own communities. This arranged marriage, for many parents, was an important ritual celebration of their daughter's entry to adulthood but also left her the choice either to stay or leave the marriage. ${ }^{12}$ Because marriage was arranged by parents, they would be responsible when the marriage did not work and so welcome their daughter back home. After her first marriage, the daughter had more freedom to choose her own husband. If she was too young, her parents might still arrange her next marriage, with her consent. ${ }^{13}$

The parentally arranged marriage usually began from an early age, even before the birth of the children. These arranged marriages were very vulnerable to divorce due to immaturity and incompatibility. ${ }^{14}$ In the

\footnotetext{
${ }^{8}$ Ibid, p. 70.

${ }^{9}$ Susan Blackburn and Sharon Bessell, 'Marriageable age: political debates on early marriage in twentieth-century Indonesia', Indonesia, No. 63 (April) 1997, pp. 107-41.

${ }^{10}$ Gavin W. Jones, "Modernization and divorce: Contrasting trends in Islamic Southeast Asia and the West", Population and Development Review 23, 1 (March1997), pp. 95-114.

${ }^{11}$ Blackburn and Bessell, 'Marriageable age”, p. 113; Geertz, The Javanese Family, p. 70 .

${ }^{12}$ Geertz, The Javanese Family, pp. 69-70.

${ }^{13}$ Rosemary Firth, Housekeeping Among Malay Peasants. New York: Humanities Press, 1966), p. 46.

${ }^{14}$ Jones, "Modernization and divorce"; Rosemary Firth, Housekeeping, p. 44; Tim B. Heaton et al., "Why is the divorce rate declining in Indonesia?" Journal of Marriage
} 
1950s, the divorce rate in Java was the highest divorce rate in the world with nearly half of all marriages ending in divorce, with the divorce mostly occurring in a couple's first parentally arranged marriage. ${ }^{15}$ There was no stigma to divorce because the first marriage was considered an experiment or probation. ${ }^{16}$ However, according to Wolf, ${ }^{17}$ this high divorce rate was more common among the abangan, ${ }^{18}$ who did not see divorce as morally wrong; while santri and priyayi tended to see divorce as morally wrong and shameful. Moreover, according to Wolf, priyayi (upper-middle class people) women tended to avoid divorce in order to secure their economic dependence on their husbands.

Prior to the 1970s, Indonesian women were very vulnerable to abusive treatment. Women were rarely consulted or given the choice of marrying for love, and when they got married, usually at an early age, they were vulnerable to being divorced unilaterally or being married polygamously or being abandoned by their husband arbitrarily. Women had no clear rights because there was no codified Indonesian law which governed marital relationships. ${ }^{19}$

The situation has changed since the 1970s. At this time, Indonesia had just started its development. The New Order government had improved roads and transportation and built many schools throughout Indonesia, especially in Java, with a primary school in every village, junior high school in every district and later, senior high school in every district. This made it easier for girls to attend school closer to home.

and Family 63, 2, (2001).

${ }^{15}$ Geertz, The Javanese Family, pp. 69.

${ }^{16}$ Firth, Housekeeping Among Malay, p. 44.

${ }^{17}$ Diane L. Wolf, Factory Daughters: Gender, Household Dynamics, and Rural Industrialization in Java, (Berkeley: University of California Press, 1992), p. 62.

${ }^{18}$ This term was firstly used by Clifford Geertz, an American anthropologist, to describe Javanese commitment to Islam. Abangan is a Muslim who is still very much influenced by Hinduism, while santri is a pious Muslim, see Clifford Geertz, The Development of the Javanese Economy: A Socio-Cultural Approach (Cambridge: Center for International Studies, Massachusetts Institute of Technology, 1956), pp. 98, 121. Abangan is also often called a nominal Muslim, while santri is often called a devout Muslim.

${ }^{19}$ June S. Katz and Ronald S. Katz, "The new Indonesian Marriage Law: A mirror of Indonesia's political, cultural, and legal systems", American Journal of Comparative Law 23, 4, 1975, p. 656; Nani Soewondo, "The Indonesian Marriage Law and its implementing Regulation”, Archipel 13, 1977, pp. 283-4. 
As a result, a large number of girls completed their first nine years of education. Some parents could support their daughters' further education even when they needed to travel a long distance or left home. With the positive consequences of education, including job opportunities, economic security and prestige, many Indonesian parents preferred that their daughters continue their studies instead of getting married. This preference can be seen, for example, in the comments of neighbours to early marriage, which were the opposite of what was heard in the 1950s. In the 1950s, if sixteen or seventeen year old girls were not married yet, they would be labeled as unmarketable (tidak laku) or spinster (perawan tua), while after the 1970s, if a seventeen-year girl was married, she tended to be looked down upon or ridiculed ("Kok kawin, masib muda! "How come she is married, she is so young!") especially if the marriage was caused by pregnancy. ${ }^{20}$

In general, there has been an increase in the age of marriage since the 1970s, not only in Indonesia but also in Southeast Asia. Education opportunities for girls might have contributed to the increasing age of marriage. In Indonesia, the enactment of the 1974 Marriage Law, which sets the minimum age of marriage, 16 years old for women and 18 years old for men, might also have contributed to the rising age of marriage. According to Hull, in Indonesia, the average age of first marriage rose to over 20 in $1985 .{ }^{21}$ According to Jones, the average age of marriage increased from less than 19.5 in 1980 to 20.9 by $1990 .{ }^{22}$ This increase continued throughout the Malay world. As a result, since the 1990s, it is common to find unmarried Malay men and women in their thirties or even not married at all throughout their lives. ${ }^{23}$

${ }^{20}$ Nancy J. Smith-Hefner, “The new Muslim romance: Changing patterns of courtship and marriage among educated Javanese youth', Journal of Southeast Asian Studies 36, 3 (October 2005), p. 451.

${ }^{21}$ Terence H. Hull, "Fertility decline in the New Order period: The evolution of population policy 1965-1990', in Hal Hill (ed.), Indonesia's New Order: The Dinamics of Socio-economic Transformation (NSW: Allen \& Unwin, 1994), pp. 136.

${ }^{22}$ Gavin W. Jones, Marriage and Divorce in Islamic South East Asia (Kuala Lumpur: Oxford University Press, 1994), pp. 108, 131.

${ }^{23}$ Gavin W. Jones, "Population and the Family in Southeast Asia", Journal of Southeast Asian Studies 26, 1 (March, 1995), p. 191; Gavin W. Jones, "Not 'when to marry' but 'whether to marry': The changing context of marriage decisions in East and Southeast Asia', in Gavin W. Jones and Kamalini Ramdas (eds), (Un)tying the Knot. Ideal 
The opportunity for study for girls also means that they have more opportunities to socialize with their opposite sex and give them more chance to know each other beyond parental oversight. ${ }^{24}$ This has changed marriage arrangements from parentally arranged marriage to personal choice marriage based on romantic love. ${ }^{25}$ Personal choice marriage based on love at a more matured age tends to last longer than parentally arranged marriage. ${ }^{26}$ As a result, the divorce rate has been gradually decreasing. This decreasing rate of divorce might also be due to economic development, which has led to an increasing number of men and women who have their own career after they graduated, reducing poverty-related causes of divorce. In addition, the enactment of the 1974 Marriage Law, which requires that divorce take place at the Religious Court, could have contributed to reducing the incidence of divorce due to its difficult process. ${ }^{27}$ Before the enactment of the 1974 Marriage Law, divorce was very easy, in that a man could just pronounce that he divorced his wife, even without the wife's knowledge, and the divorce took place. In contrast, after the enactment of the 1974 Marriage Law, a husband or a wife were forced to take their case to the Court and pay all legal expenses. To obtain a divorce, a couple had to attend at least three legal hearings. The first hearing aimed at reconciliation, the second concerned finding the result of the reconciliation process, and finally, if the reconciliation process had no positive result, the third hearing legalized the divorce procedure. ${ }^{28}$ Overall, even though there has been criticism and dissatisfaction with the 1974 Marriage Law, ${ }^{29}$ the enactment of this Law has protected women's

and Reality in Asian Marriage (National University of Singapore: Asia Research Institute (ARI), 2004), pp. 7, 51.

${ }^{24}$ Smith-Hefner, "The new Muslim romance", p. 451.

${ }^{25}$ Accoding to Anthony Giddens, romantic love is a modern concept which appeared in the late eighteenth century; it is a process of attraction to someone who can make one's life "complete". See Anthony Giddens, The Transformation of Intimacy: Sexuality, Love and Eroticism in Modern Societies (Cambridge: Polity Press; Oxford: Blackwell, 1992), p. 40.

${ }^{26}$ Hull, "Fertility decline" pp. 123-45; Jones, "Population and the Family", p. 192; Jones, "Modernization and divorce", p. 105; Wolf, Factory Daughters, p. 213.

${ }^{27}$ Jones, 'Modernization and divorce", p. 107.

${ }^{28}$ Gavin Jones, Marriage and Divorce, p. 247.

${ }^{29}$ The Law was criticized for its failure to abolish polygamy, see Susan Blackburn, "Women and citizenship in Indonesia", Australian Journal of Political Science, Canberra, 34 
rights better than what existed before its enactment.

As mentioned above, most Indonesian Muslim feminists originally came from rural areas. These women, who were born during the 1960s, were able to take advantage of the changing attitudes toward marriage and women's education. In the 1990s, when the works of non-Indonesian Muslim feminists came to Indonesia, most of these women had at least their first degree (S1) at Islamic Higher Education institutions such as the State Institute for Islamic Studies (IAIN). Some of them who understood English and Arabic could read many feminist works in their original language, while others relied on Indonesian translations of the works published in Indonesia by Mizan, LKiS and others.

\section{Global Muslim Feminism}

If we define feminism as "an awareness of the existing oppression or subordination of women because of their sex and as working to eliminate such oppression or subordination and to achieve equal gender relations between men and women", then feminists are not necessarily women because oppression and subordination of women is not caused by biological factors but by culture. Some women may contribute to the perpetuation of patriarchal culture and some men may argue for and support women's rights. With the above definition, we can regard the Prophet Muhammad (d. 632) as a feminist. Why? Prior to the birth of Islam, there were strong negative attitudes and hatred against women to the point that they were buried alive right after their birth. Women were regarded to have a lower position than men, with women regarded as equal with goods or property that could be inherited. Islam, then, elevated the position of women in many ways such as prohibiting female infanticide and giving women the right to inherit. The Prophet Muhammad treated women gently and responded positively to their quests for knowledge by, for example, setting aside one day to teach women.

(July, 1999), p. 190. The 1974 Marriage Law allows men to practice polygamy with the restriction that they have to apply for the Religious Court's permission before taking another wife. To be permitted by the Court, the husband should obtain the permission from the first wife to take another wife; to show his income to ensure that the husband will be capable of supporting more than one wife and his children; and to state that he will be capable of treating his wives and their children justly, see Department of Information, The Indonesian Marriage Law (Jakarta: Dept. of Information, 1979). 
Feminism can exist anywhere and in various forms in the world, and so is not necessarily being pioneered by the West. For example, in Egypt, Muhammad Abduh (1849-1905) ${ }^{30}$ and Qasim Amin (1863$1908)^{31}$ argued against arbitrary polygamy and showed their concern for women's education. Like Qasim Amin, who disagreed with the use of face covering among women, Huda Sha rawi (1879-1947) ${ }^{32}$ was also one among the early Muslim feminists in Egypt who argued against the veil. Later, Nawal Saadawi (b. 1931) ${ }^{33}$ criticized discriminatory treatment

${ }^{30}$ Muhammad Abduh is one of the Muslim reformists. His reformism was brought to Indonesia by Ahmad Dahlan, who found Muhammadiyah based on Abduh's reformism in 1912. However, Abduh's argument against polygamy seems to be unknown among Muhammadiyah followers or they remain silent about Abduh's argument against polygamy. In his tafsir, Al-Manaar, which was compiled by his student Muhammad Rashid Rida, Abduh argues that polygamy is definitely prohibited for fear of being unjust (anna ta'addudu 'l-zaujaat mubarromun qoth'an 'inda 'l-khauf min 'adami '\% 'adli). See Muhammad Rashid Rida, Tafsìr al-Qurān al-h. akim: Al-shabir bi-tafsìr al-Manār, Vol. 4 (ed.), (Beirut: Darul Ma'rifah, 1973), p. 350.

${ }^{31}$ Qasim Amin is famous with his two publications: The Liberation of Women (Tabrir al mara'a), published in1899 and The New Woman (al mara'a al jadida), published in 1900, in which he argued for women's education in order women can educate their children; he also argued against polygamy, women's seclusion in their house and veiling; he wanted that Egyptian women are as educated and as free as women in Europe.

${ }^{32}$ Huda Sha rawi was the founder and leader of Egyptian Feminist Union (EFU), which were concerned with education, social welfare and equality between men and women in Family Law. Upon return from her participation in an international Feminist Conference in Rome, she threw her veil into the sea to show her outrage against Egyptian traditions and authorities, whom she regarded to neglect the social welfare of their people.

${ }^{33}$ Nawal Saadawi writes both fiction and non-fiction books which have been translated from Arabic into over 20 languages, including Indonesian. Her novel, Memoirs of $A$ Woman Doctor (1958), shows her rebellious nature against discriminatory treatment to women, in which women are expected to do house works and less freedom to play outside the house; while men are free from doing house works and free to play outside the house. Another novel, Women at Zero Point (1975), criticizes the hypocrisy of Egyptian high authorities. Many of the contents of her novels seem to be based on her real life to criticize the discriminatory treatments and violence against women. She is especially against the practice of female circumcision, an old African tradition, which many Egyptian Muslims believe to have Islamic roots. This is especially discussed in one of her non-fiction books, Al-Mar'a wa'l-Jins [Woman and Sex] (1972), which caused her to be dismissed from the Ministry of Health due to her sharp criticism against theological authorities, especially in cases of female circumcision. Not only dismissed from her position, but also she was imprisoned during Anwar Sadat government in 
and violence against women in the name of Islam. In Morocco, Fatima Mernissi (b. 1940) has written many of her feminist works since the 1970s. ${ }^{34}$ In India, Asghar Ali Engineer (b.1939) not only fought for women's rights but also argued against communalism. ${ }^{35}$ In America,

1981 due to her sharp criticism to the Egyptian government. In 1988, she even had to exile from Egypt due to the threat of Islamist and political prosecution.

${ }^{34}$ Fatima Mernissi is a very productive writer, whose analysis and criticism to the dominant patriarchal culture is very sharp. Her rebellious nature to the established patriarchal tradition can be seen from many of her publication such as Beyond the Veil: Male/Female Dynamics in Modern Muslim Society, Doing Daily Battle: Interviews with Moroccan women, The Veil and the Male Elite: A Feminist Interpretation of Women's Rights in Islam, The Forgotten Queens of Islam, Scheherazade Goes West, Islam and Democracy: Fear of the Modern World, Women's Rebellion and Islamic Memory, and Dreams of Trespass: Tales of a Harem Girlhood. Like Saadawi, Mernissi’s books have been very influential among many Indonesian feminists, especially The Veil and the Male Elite. In this book, Mernissi criticizes misogynistic hadith, written in Bukhari's prestigious collection. The hadith, lan yufliba qaumun wallaw amrabum imra'atan, which has often been used to justify the prohibition of women to become household or political leader, according to Mernissi, was unacceptable hadith even though it is written in Shabih Bukhari. In this book, she also criticizes the current use of the term bijab, to cover women's body, which she argues that the term was originally used to separate between two males: the Prophet and Anas bin Malik, who was present in the Prophet's house during one of the Qur'anic revelations. See Fatima Mernissi, The Veil and the Male Elite: A Feminist Interpretation of Women's Rights in Islam (New York: Basic Books, 1991), pp. 85-87.

${ }^{35}$ Asghar Ali Engineer is also productive writer, whose writings have been influential to many Indonesian feminists. Among the most influential work that has been translated into Indonesian is The Rights of Women in Islam (New York: St Martin's Press, 1992, 1996). Chapter 3 of this book offers an alternative interpretation of the Qur'anic verse 4: 34, which has often been used to justify male leadership and violence against women. Different from most classical Qur'anic interpretations which tend to see the verse as a theological verse, and therefore that men should be the leader of the family wherever and whenever; Engineer understands the Qur'anic verse 4: 34 as a sociological verse. This means that the verse tells gender relation at the time of revelation: that at the time of revelation men were leaders of the household because some men at that time excelled over some others and because men at that time spent their money to support their family. As a result, it can be understood that this verse is not compulsory guide of gender relation wherever and whenever but shows that gender relation now can be similar or different from that is described in the Qur'an at the time of revelation. He also criticizes the use of this verse to justify violence against women. For him, the Qur'an does not prescribe beating women, but in fact it tries to prevent or postpone men from beating their wives right away when the wives made mistake, but to admonish them first and then sleep in separate bed. Different from interpreta- 
there are many Muslim feminists such as Amina Wadud, ${ }^{36}$ some of them originally from Muslim majority countries such as Riffat $\operatorname{Hassan}^{37}$ and

tion of most classical commentators such as Zamakhshari and Al-Razi who interpret wadribubunna in the verse 4: 34 as "to beat them", Engineer quotes the interpretation of Ahmed Ali, one of the Indian Qur'anic commentators, who refers to Al-Raghib Mufrodat that wadribubunna means "to have intercourse with them", see Engineer, The Rights of Women p. 49. Other famous Engineer works in relation to women are Status of women in Islam (India: Ajanta Publications, 1987), Problems of Muslim Women in India (India: Institute of Islamic Studies, 1995), Lifting the veil: communal violence and communal harmony in contemporary India (London: Sangam Books, 1995), The Quran, women, and modern society (UK: New Dawn Press Group, 2005). There are numerous other Engineer's works which advocate contextual and peaceful reading of the Qur'an.

${ }^{36}$ Amina Wadud (born 1952) is retired from Virginia Commonwealth University, USA, in 2008, but she is still academically active. Wadud's Qur'an and Woman offers a woman's perspective to the existing dominant male perspectives in understanding the Qur'an. Wadud criticizes the dominant atomistic approach [tablili] in understanding the Qur'an, offering a hermeneutics of tawhid to emphasize the unity and the coherence message of the Qur'an. In addition, she emphasizes the gendered nature of Arabic, the language used to communicate God's message in the Qur'an. For example, in Arabic, the masculine plural includes males and females, equally, unless there is indication that shows that the masculine plural is exclusive for males only such as by mentioning feminine plural. Thus, the word muslimuna means there are three or more Muslims with at least one male Muslim, unless the word muslimuna is followed by the muslimatu which can change the meaning of the former to mean that it is exclusively for males. See Wadud, Qur'an and Woman, p. 4. Following Fazlur Rahman's approach to the Qur'an, Wadud proposes contextual reading to the Qur'an acknowledging the particularistic of the context of the Qur'anic revelation in Arab and the universal message or the spirit of the Qur'an. Using this hermeneutical approach to the Qur'an, Wadud offers new understanding of the Qur'an such as on the first creation of humankind and many other controversial gender issues such as divorce, polygamy, the value of female witness, inheritance, male authority and childcare. Her second book, Inside the Gender Jihad: Woman's Reform in Islam (Oxford: One World, 2006, Wadud is more open about her personal background and the connectedness between her own experiences as a woman, her intellectual engagement in interpreting the Qur'an and her activism.

${ }^{37}$ Riffat Hassan is a professor of Religious Studies at University of Louisville, Kentucky, United States of America (USA). She is the strong advocate of women human rights, arguing that human rights are compatible with Islam and in fact, she argues that the Qur'an is Magna Carta of human rights. She is particularly against the practice of honor killing, which she argues to be un-Islamic. She is also one of the supporters of women's rights for abortion (quoting the Muslim jurisprudence that abortion in the first 120 days, before the fetus is ensouled, is accepted) and women's access to contraceptives. Even though Riffat Hassan seems to be not as productive as Saadawi and Mernissi in writing books (I do not find a book written by Riffat Hassan yet), but 


\section{Asma Barlas ${ }^{38}$ who originally come from Pakistan, and Leila Ahmed}

they all seem to be equally influential among Indonesian Muslim feminists. In her "The Issue of Woman-man Equality in the Islamic Tradition" published in Women's and Men's Liberation (New York: Green Wood Press, 1992), she argues that men and women are equal in Islam and she uses Qur'anic verse 4: 1 as the basis for gender equality. In her opinion, the verse tells that both men and women were created from the same essence, nafs-l-wahidah, and therefore, they are equal. She found that many Muslims believe that the first human created by God was Adam; then Eve was created for Adam from his left and crooked rib. According to Hassan, this belief is derived from the Bible. Hassan explains that there are four references on the creation of women in the Bible: Genesis 1: 26-27; Genesis 2: 7; Genesis 2: 18-24 and Genesis 5: 1-2. Among these four references, the most influential reference is $2: 18-24$, which state that women are created from men, which is then commonly interpreted that Adam is the main creator, while Eve is subordinate to Adam; therefore it is believed that Eve was created just to serve Adam. Studies on the other three references, for example, show that Adam, in Hebrew language, literally means "soil", but Adam is generically used to refer to human species in general, not naming individual person. The problem is that the belief that Eve is created from the left and crooked rib is written in prestigious hadith collection of $S$ aḥi Bukhäri and Sabīh Muslim and being quoted by famous Qur'anic tafsir such as Tafsir Jalalayn and Tafsir Ibn Kathir. This belief, according to Hassan, is not only derived from the Bible but also is contradictory with the Qur'anic verse 4: and should be rejected. See Hassan, Setara di Hadapan Allah, p. 65.

${ }^{38}$ Asma Barlas wrote four books: Democracy, Nationalism and Communalism: The Colonial Legacy in South Asia (Boulder, Westview,1995), "Believing Women" in Islam: Unreading Patriarchal Interpretations of the Qur'an (Austin, Texas: University of Texas Press, 2002), Islam, Muslims and the U.S. (India, Global Media Publications, 2004), and Reunderstanding Islam (Van Gorcum Press, the Netherlands, 2008); and many articles and book chapters. Among her four books, "Believing Women" in Islam is the most influential among many Indonesian Muslim feminists. This book argues that Islam is an egalitarian and anti-patriarchal religion. According to Barlas, tawhid (the notion that God is one, unique and nobody resembles or is equal to God) is the central feature of the Islamic religion; no others, neither husband nor father, can have God-like power over women. Thus, everybody is equal before God. In addition, according to Barlas, the case of Abraham presented in the Qur'an is one of the examples how Islam undermines the authority of a father, a central figure in patriarchal culture, in which Abraham left and disobeyed his father to worship idols in order to obey and worship God. Barlas also criticizes Muslim unconscious elevation of the position of sunna, tafsir and fiqh above the Qur'an. Barlas points out that this unconscious action began since the ninth century, when Syafi i (d. 819) and Tabari, one of the great Qur'anic commentators in the tenth century, unconsciously claimed their opinion not as "in my opinion" but as "the will of God". Barlas also argues that the canonization of sunna (the consensus to make the sunna as the second source of Islam) and the formalization of the four schools of law not only have made the Qur'an more untouchable but also have taken the right of the 
(b. 1940) ${ }^{39}$ from Egypt, and Azizah Al-Hibri (1943) from Lebanon. ${ }^{40}$ However, Al-Hibri is not as well known in Indonesia as the above mentioned feminists. In England, there are also many Muslim feminists who originally came from Muslim majority countries such as Ziba Mir-

contemporary Muslims to conduct their own ijtihäd, for them to understand the Qur'an directly. Barlas also reveals the political interest behind "the closure of ijtibàd" in the medieval era, when the government at that could take advantage of the "intellectual stability" by having its people to refer only to the existing four schools of fiqh: Hanafi, Maliki, Shafi i dan Hambali. The tradition of taqlid, blind reference to the existing product of ijtihad, has been maintained up to the present time. Consequently many contemporary Muslims tend to refer to the human products of figh and tafsir rather than the Qur'an, making the Qur'an unreachable for Muslims. Many Muslims can read the Qur'an but are afraid of understanding its message without referring to the classical figh and tafsir. Moreover, Barlas rejects the dominant view that Qur'an needs hadith in order the Qur'an can be understood. In contrast, she argues that it is the Hadith which needs the Qur'an to determine the validity of its content. The hadith which contradicts the Qur'an cannot be accepted. Influenced by Amina Wadud and Fazlur Rahman in their approach to the Qur'an, Barlas argues for multiple liberal readings of the Qur'an in order the message of the Qur'an on equality of human beings and the patriarchal nature of Islam can be understood.

${ }^{39}$ Leila Ahmed (1940) was born in Egypt. She worked as a professor in Women's Studies and Near Eastern studies at theUniversity of Massachusetts Amherst in 1981. Since 1999, she has been a professor in Women's Studies and Religion at the Harvard Divinity School. Her first book, Women and Gender in Islam (New Haven and London: Yale University Press, 1992) argues that Muslim women's subordination in the Middle East is not due to Islam, but the patriarchal interpretation of Islam. Like Mernissi, Ahmed pointed out that Islam was developed within andocentric and misogynist society during the Abbasid Iraq period (750-1258), in which the interpretation of Islam tends to hide the values of gender equality in Islam. In her second book, A Border Passage: From Cairo to America- A Woman's Journey (New York: Farrar Straus \& Giroux, 1999), which is autobiographic, she tells her personal experiences from her childhood in Egypt to her education in England and her teaching in America. Among others, she differentiates between the nature of the dominant "official Islam" defined by men and the peaceful "informal Islam" defined by women.

${ }^{40}$ Al-Hibri is Professor of Law at the T. C. Williams School of Law, University of Richmond, Virginia, USA. Among her publications are chapters on "Islamic Jurisprudence and Critical Race Feminism" in Global Critical Race Feminism: an International Reader (New York: New York University Press, 2000) and "An Introduction to Muslim Women's Rights" in Windows of Faith and an essay "Is Western Patriarchal Feminism Good for Third World/Minority Women?” in Is Multiculturalism Bad for Women? (1999). 
Hossaini $^{41}$ and Haleh Afshar (1944) ${ }^{42}$ from Iran. Of course there are many more global Muslim feminists, both male and female, who are not mentioned here but their works have been influential for Indonesian Muslim feminists.

\section{The Influence of Muslim Global Feminism on Indonesian Muslim Feminist Discourse}

Many works of the above mentioned Muslim feminists have been translated into Indonesian since the early 1990s, such as the works of Qasim Amin, Nawal Saadawi, Fatima Mernissi, Riffat Hassan, Asghar Ali Engineer, Amina Wadud, and Asma Barlas. Some Indonesians who were educated in the 1990s, responded to these works by conducting seminars and conferences to discuss Muslim feminism or by doing further research on Muslim feminism. ${ }^{43}$ Among Indonesian Muslim scholars

${ }^{41}$ Ziba Mir-Hosseini works as an independent consultant, researcher, and writer on Middle Eastern issues, based at the London Middle East Institute and the Centre for Middle Eastern and Islamic Law, both at SOAS, University of London, UK. Her specialization is on gender, family relations, Islamic law, and development. Among her publications are Marriage on Trial: A Study of Islamic Family Law in Iran and Morocco (London; New York: I. B. Tauris, 1993, 2002), Islam and Gender: The Religious Debate in Contemporary Iran (Princeton, N.J. ; Chichester: Princeton University Press, 1999), and (with Richard Tapper) Islam and Democracy in Iran: Eshkevari and the Quest for Reform (London; New York: I. B. Tauris, 2006). She has also directed (with Kim Longinotto) two award-winning feature-length documentary films on contemporary issues in Iran: Divorce Iranian Style (1998) and Runaway (2001). .

${ }^{42}$ Haleh Afshar wrote two books Islam and Feminisms: An Iranian Case Study (Macmillan, 1998), and Islam and the Post Revolutionary State in Iran (Macmillan, 1994) and also edited thirteen books on women and development. Like Al-Hibri, Afshar is not as famous in Indonesia as the earlier mentioned Muslim feminist.

${ }^{43}$ For example, as stated earlier that Jurnal Ulumul Qur'an led by Dawam Rahardjo invited Riffat Hassan to give her talk in Jakarta in 1993. I attended this lecture with many other Indonesian feminists, both secular and Muslim feminists, but I did not consider myself as a feminist yet at that time. In fact, at that time I rejected Riffat Hassan's argument that in Islam, men and women are equal, due to my lack of understanding of her argument and feminism. I did not even try to understand her explanation in response to my rejection and queries why she argues that in Islam men and women are equal. I just felt that my Islam was different from her and I believed I had the correct Islam because I was brought up with the conviction that women indeed subordinate to men and in reality I was treated differently as a woman. For example, my parents have six children, one of us is male. When I was a child, my mother asked her girls to 
who undertook further research, publication and training on feminism were Lies Marcos, Masdar F Mas`udi, Lily Zakiah Munir, Nasaruddin Umar, Zaitunah Subhan, Nurjannah Ismail, Maria Ulfah Anshor, Badriyah Fayumi, Siti Musdah Mulia, Abidah Al-Khalieqy, KH Husein Muhammad, and Faqihuddin Abdul Kodir. Overall, they argued against the use of religion to justify women's subordination by re-interpreting the Qur'an from the perspective of gender equalty. Due to the limits of space, I will only discuss the works and activism of a few Indonesian Muslim feminists.

Lies Marcos was one of the earliest advocates of women's rights within Islam in Indonesia. She grew up in a small town in West Java and continued her studies at the State Institute for Islamic Studies (IAIN) Jakarta. During her activism in the Perhimpunan Pengembangan Pesantren dan Masyarakat/P3M [the Centre for the Development of Pesantren and Society], she enlightened many kiayis (male pesantren leaders), including $\mathrm{KH}$ Muhammad, their wives and religious teachers in the pesantren within Nahdlatul Ulama/ $\mathrm{NU}^{44}$ by undertaking the Pelatihan Fiqh Al-Nisa' untuk Penguatan Hak-Hak Reproduksi Perempuan [the Training of Women's Fiqh to Empower Women's Reproductive Rights] in six regions throughout Java and Madura. In this training, Lies raised awareness of the inequality of men and women, which is justified by male

do household works in the morning such as washing dishes, cleaning the house and its surrounding, while my brother could be free from doing those chores. However, when the snack time came, my brother could have double portion of the food compare to what we had. Thus, I took for granted the socialization that women are subordinate to men and was surprised with Hassan's argument which was new for me. Even though I rejected Hassan's argument in the very first time I heard it, since that time, I had a big question in my head that really demanded an answer: "Does Islam subordinate women?". During my MA studies in Australia in 1995-1997, I started to learn more on feminisms: both Western and Muslim feminism. I started searching the works of Riffat Hassan, which led me to read other works of Muslim feminists such as Nawal Saadawi, Fatima Mernissi and Amina Wadud. By the time I finished my MA, I understood many of Muslim feminists' arguments and I myself declare to be a Muslim feminist. Like Riffat Hassan, I do believe that in Islam, men and women are equal.

${ }^{44} \mathrm{NU}$ is one of the largest moderate Muslim organization in Indonesia, which is often labeled as the traditionalist because they tend to conserve either local tradition or classical fiqh tradition. Many NU young generation, however, have become increasingly more liberal and progressive such as Siti Musdah Mulia, Ulil Abshar Abdalla, Marzuki Wahid, Abdul Moqsith Al-Ghozali and Faqihuddin Abdul Qadir. 
biased interpretation. She uses Arabic, which tends to be more acceptable among NU communities, rather than English. Around 1998, she went to the Netherlands to undertake her Master's degree in Anthropology at the University of Amsterdam and returned to Indonesia in $2000 .{ }^{45} \mathrm{In}$ that year, however, Lies left P3M due to a disagreement over the practice of polygamy and its practice by the director of P3M. Lies, together with other Muslim feminists within NU such as Kiayi Hussein Muhammad, founded Rahima, the Center of Education and Information of Islam and Women's Rights, a non-governmental organization which advocates for women's rights within Islam. Since 2001, Lies has been working as a Senior Program Officer on women's empowerment and Aceh programs at The Asia Foundation and continues to be supportive of Rahima and Fahmina ${ }^{46}$ activities. Lies is more of an activist, who spreads her knowledge in order to raise gender awareness through training, rather than writing books.

Masdar F Mas 'udi is the director of P3M. He wrote Islam \& Hak-Hak Reproduksi Perempuan [Islam and the Women's Reproductive Rights], which was published by Mizan in 1997. This book was written at the request of the participants in the training Fiqh al-Nisa' to address women's reproductive rights within Islam. This book offers a distinctive approach to Islam that is contextual and progressive. The book categorises Qur'anic verses into fundamental (muḅkam [clear or can

${ }^{45}$ See Clare Harvey, “Living Islam”, Inside Indonesia, 103: Jan-Mar 2011, http:/ / www.insideindonesia.org/feature/living-islam-09011391, date access 14 April 2011.

46 The Fahmina Institute was founded by young NU scholars: KH Husein Muhammad, Affandi Mukhtar, Marzuki Wahid dan Faqihuddin Abdul Kodir in Cirebon in 1999. It advocates for human rights, democracy, pluralism and gender equality. In 2008, Fahmina could found higher educational institution called Institut Studi Islam Fahmina/ISIF (The Fahmina Institute of Islamic Studies). The founders of Fahmina write productively both in English and Indonesian. One of the most famous publications is Dawrah Figh Perempuan, a training manual for women's fiqh, which is written both in Indonesian and English. Fahmina continues the roles and activities which was previously undertaken by $\mathrm{P} 3 \mathrm{M}$ in raising gender awareness within Islam not only among NU circles but also among wider audience such as women activists in Indonesia who have no Islamic educational background and even abroad such as Malaysia and the Philippines. As part of Fahmina, I was invited to be a resource person in Islam and gender training in the Philippines in December 2007 and among Indonesian women activists in January 2011. Both Rahima and Fahmina are part of Alimat [female scholars] networks, which is also part of Musawah global network. 
be easily understood]) and therefore is qat $i$ [certain]) and instrumental (mutashabih [unclear]) and therefore is zanny [uncertain]). Fundamental verses, according to Mas `udi, deal with fundamental issues such as the equality of human beings regardless of their sex, race and ethnicity (e.g. QS 49: 13), the importance of justice (QS 16: 90), human equality before the law (QS 5: 8), the importance of keeping promises and respecting agreements (QS 17: 34 and 2: 177), gender equality in the family (QS 2: 187) and treating each other well (QS 4: 19). ${ }^{47}$ These verses are regarded as fundamental because they can be easily understood and accepted, and therefore we do not need ijtihäd on these fundamental issues. Muslim scholars (ulama) do not need ijtihäd on whether it is important or not to advocate for justice because justice is important wherever and whenever. What needs ijtibäd is the practicalities of how to advocate for justice in different contexts, times and places. Instrumental verses, according to Mas `udi (1997), are the verses which deal with practicalities such as the verses on inheritance. In his opinion, what is fundamental in the division of inheritance is to stand for justice. ${ }^{48}$ Mas 'udi's book also counters the mainstream fiqh which tends to emphasize women's obligation such as the obligation to serve their husband. In contrast, this book emphasizes women's reproductive rights such as the right to choose a prospective husband, to enjoy sexual relations, to have children, to decide when to be pregnant, to take care of their children, to have reproductive leave and to divorce. The influence of non-Indonesian Muslim feminist works on his book, for example, can be seen in his quoting two works of Mernisi: Ratu-ratu Islam ${ }^{49}$ and Women and Islam: an Historical and Theological

${ }^{47}$ Masdar F Mas`udi, Islam dan Hak-hak Reproduksi Perempuan. Dialog Fiqib Pemberdayaan (Bandung: Mizan, 1997), p. 32.

${ }^{48} \mathrm{Ibid}, \mathrm{p} .33$. This Mas udi's approach to Islam is derived from his understanding of one of the works of Abu Ishaq al-Shatiby (d. 1388), an Andalusian legal scholar: Al-Muwafaqaat fi Usul al-Sharia (Dar al-Kutub al-Ilmiyyah, Beirut, n.d.). This book is commonly cited, not only by Mas'udi but also other Muslim scholars who argue for substantive approach to shari a. In this book, Shatiby emphasizes that the main aim of shari'a (maqăsid al-shari a) is maslaḥạ̣ (welfare and justice).

${ }^{49}$ This book is translated and published by Mizan in 1994 from The Forgotten Queens of Islam, published in Cambridge by Polity Press in 1993. The limited number of English books that Mas 'udi quotes may be due to his limited English ability compared to his Arabic ability. His better ability in Arabic can be seen from most of the Arabic sources that he quotes in this book. 
Enquiry and Ahmed's book Women and Gender in Islam.

Lily Zakiah Munir is the founder and the Director of the Center for Pesantren and Democracy Studies, Jombang, Indonesia (CEPDES). Like Lies and Masdar F Mas 'udi, Lily also comes from NU circles. She publishes both in Indonesia and English. She also seems to be quite active internationally, publishing and presenting her papers internationally and being a fellow abroad, such as when she was Islam and Human Rights Fellow at Emory University, Atlanta, USA, in 2003. One of her earliest edited books is Memposisikan Kodrat: Perempuan dan Perubahan dalam Perspektif Islam [Positioning Pre-determined Character: Women and Change in Islamic Perspectives], which contains articles written by both male and female scholars such as Abdurrahman Wahid, Ali Yafie, Djohan Effensi, Quraish Shihab, Masdar F Masudi, Nasaruddin Umar and Zakiah Daradjat. ${ }^{50}$ Even though she did not acknowledge it, Riffat Hassan's influence can be clearly seen in Munir's chapter. For example, from the title itself, which is "Hak Asasi Perempuan dalam Islam: Antara Idealisme dan Realitas" [Women's rights in Islam: between idealities and realities], ${ }^{51}$ and the discussion on the equal status of men and women based on Qur'anic verse 4: 1 in this chapter, it is clear that Munir's chapter is based on Riffat Hassan's articles “Are Human Rights Compatible with Islam? The Issue of the Rights of Women in Muslim Communities" and "The Issue of Woman-man Equality in the Islamic Tradition". The influence of other non-Indonesian Muslim feminists such as Engineer, Wadud, Barlas, Ahmed, Mernissi and Hassan can also be seen in her English publications such as "General Introduction to Islamic Law"52 "Islam, Humanity, and Equality for Women," 53 "Islamic

${ }^{50}$ Lily Zakiah Munir (ed.), Memposisikan Kodrat: Perempuan dan Perubahan dalam Perspektif Islam (Bandung: Mizan, 1999).

${ }^{51}$ See Munir, "Hak Asasi Perempuan dalam Islam: Antara Idealisme dan Realitas" in Memposisikan Kodrat, pp. 51-64.

${ }^{52}$ See Lily Zakiah Munir, "General Introduction to Islamic Law”, http:// www.lfip.org/laws718/docs/lily-pdf/Introduction_to_Islamic_Law.pdf, date access 15 April 2011.

${ }^{53}$ See Lily Zakiah Munir, "Islam, Humanity, and Equality for Women”, http:/ / www.lfip.org/laws718/docs/lily-pdf/Islam_Humanity_and_Equality_for_Women.pdf, date access 15 April 2011. 
Fundamentalism and Its Impact on Women", 54 "Women, Islam and Human Security", 55 "Gender Mainstreaming in Southeast Asia", 56 "Has Sharia brought justice?", 57 "Islam, Modernity and Justice for Women", 58 "Islam, Gender, and Formal Shari'a in Indonesia", 59 "Islam and Politics", 60 "Misunderstanding of polygamy lingers in Islam", "N1 "Nurturing tolerance in Pesantren", "Q2 "Querying Polygamy Award", "3. "Sharia and Justice for

${ }^{54}$ See Lily Zakiah Munir, "Islamic Fundamentalism and Its Impact on Women”, http:/ /www.lfip.org/laws718/docs/lily-pdf/Islamic $\% 20$ Fundamentalism $\% 20$ and $\% 20$ Its $\% 20$ Impact $\% 20$ on $\% 20$ Women.pdf, a paper presented at the Association of Asian Studies (AAS) Forum conducted at the Hilton Hotel, New York, March 27-30, 2003, date access 15 April 2011.

${ }^{55}$ See Lily Zakiah Munir, "Women, Islam and Human Security", http:/ /www. lfip.org/laws718/docs/lily-pdf/Women, \%20Islam\%20and\%20Human\%20Security. pdf, date access 15 April 2011.

${ }^{56}$ See Lily Zakiah Munir, "Gender Mainstreaming in Southeast Asia”, http:// www.lfip.org/laws718/docs/lily-pdf/Gender_Mainstream_CSIS.pdf, date access 15 April 2011.

${ }^{57}$ See Lily Zakiah Munir, "Has Sharia brought justice?", this paper was published in the Jakarta Post 17 March 2003, http:/ /www.lfip.org/laws718/docs/lily-pdf/ Has_Sharia_brought_justice.pdf, date access 16 April 2011.

${ }^{58}$ See Lily Zakiah Munir, "Islam, Modernity and Justice for Women", this paper presented at the Islam and Human Rights Fellow Lecture, October 14, 2003, organized by the Islam and Human Rights Project, School of Law, Emory University, Atlanta, GA, http://www.lfip.org/laws718/docs/lily-pdf/Islam_Gender_and_Modernity. pdf, date access 16 April 2011.

${ }^{59}$ See Lily Zakiah Munir, "Islam, Gender, and Formal Shari’a in Indonesia", http://www.lfip.org/laws718/docs/lily-pdf/Islam_Gender_and_Formal_Sharia.pdf, date access 16 April 2011.

${ }^{60}$ See Lily Zakiah Munir, "Islam and politics", this paper was presented at the International Seminar on "Islam and Universal Values: Islam's Contribution to the Construction of a Pluralistic World," convened by the Embassy of Switzerland in Jakarta, 18 March 2004, http://www.lfip.org/laws718/docs/lily-pdf/ISLAM_AND_POLITICS. pdf, date access 16 April 2011.

${ }^{61}$ See Lily Zakiah Munir, "Misunderstanding of polygamy lingers in Islam", this paper was published in the Jakarta Post, 24 May 2003, http://www.lfip.org/laws718/ docs/lily-pdf/Misunderstanding_of_Polygamy.pdf, date access 17 April 2011.

${ }^{62}$ See Lily Zakiah Munir, "Nurturing tolerance in Pesantren", this paper was published in the Jakarta Post, 5 September 2003, http://www.lfip.org/laws718/docs/ lily-pdf/NURTURING\%20TOLERANCE\%20IN\%20PESANTREN.pdf, date access 17 April 2011.

${ }^{63}$ See Lily Zakiah Munir, "Querying Polygamy Award”, this paper was published in the Jakarta Post, 2 August 2003, http:/ / www.lfip.org/laws718/docs/lily-pdf/Query- 
Women", "Wo "Women, Islam and Human Security", ${ }^{65}$ and many others. ${ }^{66}$ Other than being influenced by contemporary Muslim feminists, Munir's writings are also influenced by Abu Ishaq al-Shatiby (d. 1388), who offers a substantive approach to shari $a$, and Abdullahi An-Na im, a human rights advocate from Sudan who is currently Charles Howard Candler Professor of Law at Emory Law School, Emory University, Atlanta, GA, U.S.A. ${ }^{67}$ Overall, Munir argues that Islam is a religion which brings blessings to the whole universe. To achieve this mission, Munir, like Wadud and other Muslim feminists, argues for a dynamic, contextual, substantive and progressive interpretation of Islam. She opposes the fundamentalist agenda of formalizing the implementation of shari a, which she argues is far from achieving maqasid al-shar ' $a$, that is maslaha (welfare and justice). Like Riffat Hassan and An-Na im, Munir argues that women's human rights are compatible with the Islamic spirit of liberation for the oppressed. Like Lies Marcos, Masdar F Mas `udi and Asma Barlas, Munir criticizes the tendency of the majority of Muslims to regard classical fiqh as sacred and the only true fiqh/understanding of Islam.

While Indonesian Muslim feminists are influenced by nonIndonesian Muslim feminists, the former are not copying the latter's works, but instead synthesizing their works and producing something

ing_Polygamy_Award.pdf, date access 17 April 2011.

${ }^{64}$ See Lily Zakiah Munir, "Sharia and Justice for Women", this paper was presented at the symposium on "Gender and Islam in Southeast Asia" at Passau University, Passau, Germany, September 29 - October 3, 2005, http://www.lfip.org/laws718/docs/ lily-pdf/Sharia_and_Justice_for_Women.pdf, date access 17 April 2011.

${ }^{65}$ See Lily Zakiah Munir, "Women, Islam and Human Security", this paper was presented at the $17^{\text {th }}$ Asia Pacific Roundtable: Confidence Building and Conflict Reduction, Kuala Lumpur, 6-9 August, 2003, http://www.lfip.org/laws718/docs/lily-pdf/ Women_in_Islam.pdf, date access 18 April 2011.

${ }^{66}$ To have access to Munir's other publications, see http://www.lfip.org/ laws718/link1.htm, date access 18 April 2011.

${ }^{67}$ One of An-Naim's most quoted books is Toward an Islamic Reformation: Civil Liberties, Human Rights and International Law (Syracuse, NY: Syracuse University Press, 1990, soft-cover edition by American University in Cairo, Egypt, 1992). This book has been translated and published in Arabic (1994), Indonesian (1995) Russian (1999), and Farsi (2003). This books divides Qur'anic verses into Meccan and Madinan verses arguing that verses revealed in Mecca has more universal message, while verses revealed in Madina has more particular message and therefore need to be interpreted contextually. 
new, which has not yet been discussed by any non-Indonesian Muslim feminist. This can be seen, for instance, in the works of Nasaruddin Umar. Umar was born in Sulawesi in 1959. He started his education in the pesantren and then continued his studies at IAIN, with his first degree from IAIN Ujung Pandang and his Masters and Doctoral studies from IAIN Jakarta. During his doctoral studies, he became a visiting student in several universities abroad such as McGill University, Canada, Leiden University, Netherlands and Paris University, France. He published many parts of his $\mathrm{PhD}$ dissertation in different Indonesian journals and in a book entitled Argumen Kesetaraan Jender: Perspektif Al-Qur'an in 1999, and reprinted in 2010. This book, other than being influenced by nonIndonesian Muslim feminists such as Riffat Hassan, Fatima Mernissi, Amina Wadud and Leila Ahmed, offers something new: identifying gender terms used in the Qur'an. For instance, this book claims that the Qur'an uses the terms dhakar (male) and untha' (female) to refer to biology, while using rijal (masculine) and nisa'(feminine) to refer to gender or roles expected to be performed by men and women. Thus, people are biologically determined (kodrat), being born either male or female, but they can become masculine or feminine based on the roles they choose and/or construct. ${ }^{68}$

This finding is important in reading the Qur'an, especially the Qur'anic verses 4: 34 and 2: 228. According to Umar, not all males (dhakar) can become masculine (rijal). For example, in the Qur'anic verse 4: 34, the person can become rijal if the person fulfills at least two requirements: (1) being superior to his/her partner; and (2) spending his/her money to support his or her family. Because masculinity is not biologically determined, either male (dhakar) or female (untha') can become masculine (rijal). This finding is significant in challenging the common interpretations of Qur'anic verse 4: 34, that men are biologically determined to become leader of the family, and verse 2: 228, that the man's position is naturally above the women. With this new finding, it is possible to understand leadership as NOT biologically given, but achieved by fulfilling at least the above two requirements. This means that those who can fulfill the two requirements, either male or female, can be rijal who

${ }^{68}$ See Nasaruddin Umar, Argumen Kesetaraan Jender: Perspektif Al-Qur'an (Jakarta: Paramadina, 1999). 
leads the family. Similarly, those who cannot fulfill the two requirements, either male or female, cannot be rijal who leads the family. Thus, a male will remain dhakar, but not rijalif (1) he is not superior to his spouse, for example, his education or income is lower than his wife's education or income; and (2) if he cannot spend his money to support his family. In contrast, a female can become rijal if (1) she is superior to her spouse, for example, her education or income is higher than her husband's; and (2) if she spends her money to support her family. At the time of revelation, becoming rijal might usually be accomplished by males, but it is not necessarily the case that there were no women who became rijal at that time. That is why the Qur'anic verse 4: 34 states "on the basis that Allah has put some of them superior than others" which means that 'some of them' can be interpreted as either male or female with the result remaining the same: "some men are superior to women" or "some women are superior to men", but that not all men are naturally superior to women.

In addition, that the word rijal does not necessarily mean male as, for example, when we use the term rijal al-hadith. Rijal al-hadith means the expert of the hadith or the person who transmits the hadith, and is not necessarily biologically male. One of the most famous transmitters or experts of the hadith is Siti Aisyah, the wife of the Prophet Muhammad. From this new finding of Umar, the differentiation of gender and biological terms, we can see the value of justice emphasized in the Qur'an: the Qur'an appreciates or elevates a person's position based on achievement, not biology.

\section{E. Opposition to Muslim Feminism}

However, not all Indonesian Muslims agree with the discourse of feminism. Among the most vocal arguing against feminism is Hizbut Tahrir Indonesia (HTI). These people argue that feminism is a Western product, which Muslims do not need at all. Among their publications, which clearly oppose feminist discourse, is, for example Revisi Politik Perempuan written by two young Muslim women, Najmah Sa idah and Husnul Khatimah, who had just graduated with their first degree (S1) from Institut Pertanian Bogor and Universitas Padjadjaran (2003). This book criticizes the works of Muslim feminists such as Asghar Ali Engineer, Amina Wadud, Fatima Mernissi, Nawaal Saadawi and Riffat Hassan who attempt to reinterpret the Qur'an. They argue that these 
scholars have been affected by Western secularism and liberalism. For Muslims, they argue, Islam is the only solution, so they do not need feminism to solve the problems of Muslim women. They are against any Western concepts such as capitalism, democracy and liberalism. Another example of their publications arguing against feminism can be found in the monthly magazine of Muslimah HTI, Al-Wa 'ie no. 124 Tahun XI, 1-31 Desember 2010, arguing that only Islam elevates women's position ["Hanya Islam yang Memuliakan Wanita]. For Iffah Rochmah, the spokesperson of Muslimah HTI, gender equality is misleading ["Kesetaraan Jender: Salah Arah"]. She argues that the main cause of the oppression of women is the application of a capitalist economic system which has led Indonesian leaders to prioritize their own personal interests and parties, ignoring the condition of their people, including women. This adoption of a capitalist economic system has resulted in structural poverty. Iffah Rochmah also blames the idea of gender equality for causing dissatisfaction among women regarding their position in the family and society system, causing women to compete with men in all aspects of life, and destroying the existing harmonious gender relations which differentiate roles and the positions of men and women. In her view, with gender equality, women are motivated to have the same roles and positions as men, causing women to be indoctrinated with the assumption that the home is a jail for women, preventing them from working in the public sector and believing that motherhood is a form of slavery, causing fewer women to assume the roles of a mother and no one being fully responsible for the education of children. In addition, Iffah Rochmah argues that women have become more miserable due to the abolition of laws which specifically protected women by giving them special treatment in their workplaces such as giving them maternity leaves and ensuring they did not work the night shift. For her, gender equality, with all its programs, clearly adds problems, not solutions for women. ${ }^{69}$

${ }^{69}$ In my opinion, Iffah Rochmah's rejection to the concept of gender equality is partly due to her misunderstanding of it. Gender equality is not that men and women to have the same roles but to have flexible roles: not based on sex, but based on professionalism, context, skill and availability of time. For example, when a woman is busy earning money for the family, while her husband is jobless, it would be fair if the husband do house works (such as cooking, ironing and cleaning the house) and looks after his children due to his availability of time. Similarly, it would be fair for a 
The last example of the opposition to feminist ideas that I want to present is a novel entitle Kemi, written by Adian Husaini, the leader of Dewan Dakwah Islam Indonesia [the Islamic Missionary Council of Indonesia]. This novel is an indirect but sharp criticism of liberalism and feminism. The protagonists of this novel are described as selling Islam for the sake of liberal thinking and gender projects, which are usually funded by Western sponsor. The end of the novel describes the protagonists' as having a very unhappy ending: Kemi, one of the best students in a pesantren ends up insane; a liberal kiayi who is famous in West Java, repents for being a liberal thinker but dies in the seminar room; and Siti, a liberal activist and advocate of gender equality, ends up repenting for being a liberal thinker and gender activist by returning to her parents who have a pesantren. ${ }^{70}$ Thus, in this novel, liberal thinking and gender equality are woman to do house works and take care of her children, when her husband is busy earning money for the family. The different between Muslim feminist and Islamist feminist (I categorize Muslimah HTI as Islamist feminist) on gender roles is that: according to Muslim feminists, men and women should have complementary roles based on their professionalism, availability of time, situation and context, not merely determined by their sex, as I explained above. On the contrary, according to Islamist feminists, roles of men and women should be determined by sex. For them, men should be the family breadwinner, while women should be the wife and mother, serving the husband and taking care of their children. These gender roles would be ideal if both men and women could happily assume these roles, but would be problematic if for some reasons, for example, the husband is incapable of earning money, while the wife can easily make money. This could result in a wife's having too much burdens, while her husband's having too much rights without burden, which lead to unjust and unequal gender relation.

${ }^{70}$ I received these three publications from one of my doctoral students, one of the HTI activists, who argue against feminism. As a way to oppose my ideas on Muslim feminism in our class of Gender Education at the Postgraduate Program of Universitas Islam Negeri (UIN) Bandung, he politely gave me these three publications. I actually have read the first book he gave me in 2004, when one of the female HTI activists lent me and invited me to come to the book discussion, in which I could meet the two authors of this book. The two authors of this book politely gave me a chance to chat with them. During our conversation, I could see the big discrepancy of knowledge in Islamic studies between these two young writers and the Muslim feminists they criticize especially Amina Wadud and Fazlur Rahman, who have doctoral level in Islamic studies with fluent oral and written Arabic language. In my opinion, these two writers seem not to understand well what many Muslim feminists intend to deliver in their works. The writers seem to be unable to differentiate between Qur'an and its interpretation; that the Qur'an, to be implemented, in Muslim daily lives should be firstly understood and interpreted; that the earlier and classical interpretations of the Qur'an were written 
seen as Western imported ideology, which are misleading and dangerous for Muslim men and women.

\section{F. Conclusion}

Diversity is a blessing. The coming of the influence of global Muslim feminism has provided many Indonesian Muslims with an alternative way of seeing Islam and the relationship of men and women to the existing dominant literal approach to Islam, which sees men as naturally superior to women. However, it is not easy to accept new ideas, especially when the term 'feminism' and the concept of gender originally come from the West. Even though these two are substantially not in conflict with Islamic values of equality and justice, the origins of these words in the West, which has historically been colonialist and currently dominates the economic and political affairs of the East, has hindered the acceptance of feminist ideas among some Muslims, including those associated with Muslimah HTI. The way Muslimah HTI, Adian Husaini, Najmah Saidah and Husnul Khatimah see Islam and feminism seems to fit Moghissi's common characteristics of fundamentalists: anti modernity, anti democracy and anti feminism. ${ }^{71}$ However, they are not against a modern life style as such since they use sophisticated technologies such as computers and internet. Fundamentalists, according to Munir, believe in religious doctrines which restrict women. They restrict women in the domestic sphere on the basis of shari'a and 'kodrat' (nature). Many fundamentalists follow the opinion of Hasan al-Bana, a less radical ideologue from Egypt, that a "women's place is the home, and their primary roles are mother, wife and housekeeper" and Abul A'la al Mawdudi, who argues that to preserve the chastity of women, which he believes to be a basic human right, women should be kept in the house and in purdah. ${ }^{72}$

I was one of the followers of fundamentalist thinking when I was a single undergraduate student, imagining how ideal life would be if I by human beings and therefore classical tafsir or figh works are not sacred, but open to criticism; and that contemporary Muslim scholars have the same right with the classical scholars to interpret the Qur'an contextually.

${ }^{71}$ See Haideh Moghissi, Feminism and Islamic Fundamentalism (London: Zed Books, 1999), p. 70.

${ }^{72}$ Mayer A.E. in Munir, "Islamic Fundamentalism", p. 3. 
became a housewife, who would lovingly serve my husband and take care of my children at home. I saw women to be naturally subordinate to men and therefore to be guided, taught and led by men. The influence of fundamentalism came to my life when I joined a weekly youth gathering at Salman mosque, Bandung, where I read some of the works of al-Bana, Mawdudi and other followers of Ikhwanul Muslimin such as Zaynab alGhazali. That was why I initially rejected Riffat Hassan's argument that in Islam, men and women are equal, because within fundamentalism, men are regarded to be superior to women and naturally leaders of women.

After my marriage, however, I found many of the ideals of fundamentalist thought to be utopian, unrealistic and problematic, which led me to critically re-think and even challenge these ideas. The process of changing ways of seeing Islam, from fundamentalist to feminist, however, took a bit of time and extra effort because it takes time to accept new ideas, especially in relation to women's issues. Reading and engaging the discourse of Muslim feminism can be one of the ways to understand new ideas of Muslim feminists. This has led me to come to the position of agreeing with many non-Indonesian and Indonesian Muslim feminists, such as Riffat Hassan, Amina Wadud, Fatima Mernissi, Asghar Ali Engineer, Lily Zakiyah Munir, Zaitunah Subhan, Nasaruddin Umar, Musdah Mulia and others, who believe that Islam is a progressive religion which elevates women's position but under patriarchal interpretation of the Qur'an, has returned women back to pre-Islamic Arab tradition. Therefore, to return to the Islamic spirit of gender justice and equality, Qur'an has to be continually re-interpreted from the perspective of gender equality.

I am among the fortunate women who were born in the late 1960s, which allowed me to pursue my education and become empowered by the growing influence of Muslim feminist discourse in Indonesia. I cannot imagine being born earlier in the 1950s, when I might have been the subject of under-aged or parentally arranged marriage, divorced unitarily or married polygamously without my consent, or became the victim of maternal mortality due to early marriage. The New Order government had many weaknesses, but to its credit it elevated women to a better position by providing a codified marriage law and education facilities for both men and women. Ideally, the current government would continue 
previous efforts of elevating Indonesian women into a better position. For example, they could respond to the call of Indonesian feminists to amend the 1974 Marriage Law, especially regarding the abolition of polygamy and changing the rigidly imposed roles of men and women, so that instead of being based on sex they would instead be based on professionalism, the situation and context. 


\section{BIBLIOGRAPHY}

Ahmed, Leila, Women and Gender in Islam: Historical Roots of a Modern Debate. New Haven: Yale University Press, 1992.

----, A Border Passage: From Cairo to America-A Woman's Journey. New York: Farrar Straus \& Giroux, 1999.

Blackburn, Susan, 'Women and citizenship in Indonesia', Australian Journal of Political Science, Canberra, 34, July, 1999.

---- and Bessell, Sharon, "Marriageable age: political debates on early marriage in twentieth-century Indonesia", Indonesia, No. 63, April 1997.

Engineer, Asghar Ali, The Rights of Women in Islam, New York: St Martin's Press, 1992, 1996.

Firth, Rosemary, Housekeeping Among Malay Peasants, New York: Humanities Press, 1966.

Geertz, Clifford, The Development of the Javanese Economy: A Socio-Cultural Approach, Cambridge: Center for International Studies, Massachusetts Institute of Technology, 1956.

Geertz, Hildred, The Javanese Family: A Study of Kinship and Socialization, USA: The Free Press of Glencoe, 1961.

Giddens, Anthony, The Transformation of Intimacy: Sexuality, Love and Eroticism in Modern Societies, Cambridge: Polity Press; Oxford: Blackwell, 1992.

Hassan, Riffat, "Members, One of Another: Gender Equality and Justice in Islam", http://www.religiousconsultation.org/hassan.htm, date access 7 April 2011.

----, "Are Human Rights Compatible with Islam? The Issue off the Rights of Women in Muslim Communities", http://www. religiousconsultation.org/hassan2.htm, date access 7 April 2011.

---- and Mernissi, Fatima, Setara di Hadapan Allah, Yogyakarta: LSPPA, 1996.

Heaton, Tim B. et al., "Why is the divorce rate declining in Indonesia?" Journal of Marriage and Family 63, 2, 2001.

Hornby, AS, Oxford Advanced Learners Dictionary of Current English, Oxford: 
Oxford University Press, 1987.

Hull, Terence H., "Fertility decline in the New Order period: The evolution of population policy 1965-1990", in Hal Hill (ed.), Indonesia's New Order: The Dinamics of Socio-economic Transformation, NSW: Allen \& Unwin, 1994.

Husaini, Adian, Kemi, Jakarta: Gema Insani Press, 2010.

Jones, Gavin W., Marriage and Divorce in Islamic South East, Asia. Kuala Lumpur: Oxford University Press, 1994.

----, "Population and the Family in Southeast Asia", Journal of Southeast Asian Studies 26, 1, March 1995.

----, "Modernization and Divorce: Contrasting Trends in Islamic Southeast Asia and the West", Population and Development Review 23, 1, March1997.

----, "Not 'when to marry' but 'whether to marry': The changing context of marriage decisions in East and Southeast Asia", in Gavin W. Jones and Kamalini Ramdas (eds), (Un)tying the Knot: Ideal and Reality in Asian Marriage, National University of Singapore: Asia Research Institute (ARI), 2004.

Karam, Azza M., Women, Islamism and the State: Contemporary Feminisms in Egypt, New York: St Martin’s Press, 1998.

Katz, June S. and Katz, Ronald S., "The New Indonesian Marriage Law: A Mirror of Indonesia's Political, Cultural, and Legal Systems”, American Journal of Comparative Law 23, 4, 1975.

Mas'udi, Masdar F., Islam dan Hak-hak Reproduksi Perempuan. Dialog Fiqih Pemberdayaan, Bandung: Mizan, 1997.

Mernissi, Fatima, The Veil and the Male Elite: A Feminist Interpretation of Women's Rights in Islam, New York: Basic Books, 1991.

Moghissi, Haideh, Feminism and Islamic Fundamentalism, London: Zed Books, 1999.

Munir, Lily Zakiah, Memposisikan Kodrat: Perempuan dan Perubahan dalam Perspektif Islam, Bandung: Mizan, 1999.

----, "Islamic Fundamentalism and Its Impact on Women", paper presented at the Association of Asian Studies (AAS) Forum conducted at the Hilton Hotel, New York, March 27-30, 2003. 
An-Naim, Abdullahi Ahmed, Toward an Islamic Reformation: Civil Liberties, Human Rights and International Law, Syracuse: Syracuse University Press, 1990.

Nurmila, Nina, Women, Islam and Everyday Life. Renegotiating Polygamy in Indonesia, London: Routledge, 2009.

Rị̣a, Muhammad Rashid, Tafsìr al-Manār, Beirut: Darul Ma'rifah, 1973.

Rochmah, Iffah, "Kesetaraan Jender: Salah Arah", Al-Wa 'ie: Media Politik dan Dakwah, Membangun Kesadaran Umat, no. 124 Tahun XI, 1-31 Desember 2010.

Saadawi, Nawal El, Memoirs of a Woman Doctor, trans. Catherine Cobham, U.K: Saqi Books, 1989.

----, Woman at Zero Point, trans. Sherif Hetata, London and New York: Zed, c1983, 2006.

Sa'idah, Najmah dan Khatimah, Husnul, Revisi Politik Perempuan, Bogor: IDeA Pustaka Utama, 2003.

Smith-Hefner, Nancy J., "The New Muslim Romance: Changing Patterns of Courtship and Marriage among Educated Javanese Youth", Journal of Southeast Asian Studies 36, 3, October 2005.

al-Shatiby, Abu Ishaq, Al-Muwafaqaat fi Usul al-Sharia, Dar al-Kutub alIlmiyyah, Beirut, n.d.

Soewondo, Nani, "The Indonesian Marriage Law and its implementing Regulation", Archipel 13, 1977.

Umar, Nasaruddin, Argumen Kesetaraan Jender: Perspektif Al-Qur'an, Jakarta: Paramadina, 1999.

Wadud-Muhsin, Amina, Qur'an and Woman, Kuala Lumpur: Penerbit Fajar Bakti, 1992.

----, Qur'an and Woman: Rereading the Sacred Text from a Woman's Perspective, New York: Oxford University Press, 1999.

----, Inside the Gender Jihad: Women's Reform in Islam, Oxford: Oneworld, 2006.

Wolf, Diane L, Factory Daughters: Gender, Household Dynamics, and Rural Industrialization in Java, Berkeley: University of California Press, 1992. 